\title{
Modeling an Assessing Rubric: Reflections of Red Ink
}

\author{
Robert Joseph Skovira \\ Robert Morris University, Moon Township, PA, USA
}

\author{
skovira@rmu.edu
}

\begin{abstract}
The paper presents a rubric to be used in evaluating student's efforts in a course whose subject matter is four framing conceptions: global, economic, social cultural, and ethical. The course is a requirement for an ABET accredited program. These are given as the grounds for constructing the rubric. The paper also reports on the course's practices: reports.
\end{abstract}

Key words: assessment, rubric, global, economic, social cultural, and ethical framing conceptions, critical thinking.

\section{Introduction}

The essay is descriptive and analytic, reflective of the experiencing of activities and events (practices) of an undergraduate senior-level course in a computer information systems curriculum. Over the time of 15 weeks, the course is designed to add another component to the "mindset" or "decision-making style" (Rowe \& Mason, 1989) of future "educated" information systems (IS) professionals.

The incentive and motivation for the study of the framing conceptions and the issues are the future decision making situations in which the students, as future information systems (IS) professionals, undoubtedly will find themselves engaged when working in organizations (some already are there either as interns or full-time employees).

\section{The Problem}

The essay's problem is the construction of a rubric assessing the course's outcomes. By evaluating a course's results and consequences, we perhaps can evaluate an accredited program's effects. This concern is based on the problematics of the course.

\section{The Course}

The course is an ecology of conceptions (the global, the economic, the social-cultural, and the

Material published as part of this publication, either on-line or in print, is copy righted by the Informing Science Institute. Permission to make digital or paper copy of part or all of these works for personal or classroom use is granted without fee provided that the copies are not made or distributed for profit or commercial advantage AND that copies 1) bear this notice in full and 2) give the full citation on the first page. It is permissible to abstract these works so long as credit is given. To copy in all other cases or to republish or to post on a server or to redistribute to lists requires specific permission and payment of a fee. Contact Publisher@InformingScience.org to request redistribution permission. ethical), framing issues of computing or information systems and organizational information use, and practices aimed at fostering habits of critical thinking. It is a second semester and senior level course required in ABET accredited programs. The course is a construction of a logical space, a rationality for the issues facing members and future members of the profession. 


\section{The Course's Problematics}

The first problematic for this course is a descriptive elaboration of the subject matter and practices as a means of creating and practicing a sustainable habit of critical thinking about issues of concern to future IS professionals. There is a second problematic which is about making meaningful the experience of teaching and perhaps taking this course. The paper is a construction of sense about the course. It is an intermediate document, standing between a semester-long sequence of activities and events which are historical (and are the circumstances) to a future planned semester-long sequences of activities and events (practices), guided by the map of the course's syllabus. It is an attempt to answer the question: did the course through the framing conceptions, and discussion of issues, provide an perspective, an organized way of thinking (critical consideration) by organizing activities and events, about issues of concern for future IS professionals? This is the descriptive elaboration or the writing up of the sense of the course (Geertz, 1973).

\section{Thinking Critically a Long-term End}

The long-term goal of the course is to have students think critically about issues of information systems and information use or computing. The course is a situation for the development and practice of a habit of critical thinking. The focus of the aiming is not the subject matter nor the practices of the course; these are concrete means of growing a habit of doing critical thinking, a habit of problem solving, or of decision making.

Critical thinking is the habit of applying the framing conceptions of the course to the issues of the course. Thinking critically is an important aspect of an IS professional's style of decis ion making within organizational situations. It is an ability to be developed in a course's practices as an aspect of a curriculum's (or program's) goal. Critical thinking is the ability to analyze and explain problematic affairs situationally and to clarify and elaborate solutions and decisions appropriately addressing the affairs (Córdoba, 2007a, 2007b; Halpren, 1998; McBann et al, 2007; Paul \& Elder, 2006).

\section{Issues of Computing}

According to Hauser (1986), issues arise when interacting but contradictory assertions about the world, actions, or results of actions, all of which are value-based, are in play, creating uncertainty or conflict in situations. The problem of describing and analyzing issues is the problem of uncovering, describing, and analyzing values which interact and sometimes contradict each other.

Some of the issues investigated are: Freedom of expression in cyberspace; Intellectual property; Privacy and access to information; Security and cybercrime; Liability, reliability, and safety of software and digital devices; Fair competition and Internet access; Loyalty and whistle blowing, and Outsourcing of IS jobs.

\section{Conceptions Framing Issues}

The focus also is on the content, consisting of the conceptions or frames of the global, economic, social cultural, and ethical subject matter, which must be developed and elaborated in order to create a conceptual frame and foundation, which works best when silent, "tacit", or unconscious, as one of the instrumentalities (all courses in a curriculum are really about this) by which the habit of doing critical thinking on or about issues is grown. Over the course of a semester, the intention is to grow a student's framing conceptions and endeavors to sustain a questioning attitude on issues of concern for future IS professionals and decision makers. 
A course normally adds warranted and canonical conceptions and vocabularies, as its subject matter, to "thinking frames" or "decision frames" of students (Russo \& Schoemaker, 1990). They are canonical concepts with "warrants" because they are grounded in the discipline's theories and public research. These conceptual frames provide a language for discussion of topics. From the discipline's point of view, these conceptions frame and ground an IS professional's experience. The framing conceptions are individually and holistically perspectives or ways of approaching any issue arising in the analysis, design, and development of information systems. Framing conceptions structure the meanings of the practices (Fairhurst \& Sarr, 1996). They present takes or possible ways of interpretation. Framing conceptions are habitual mental models (Lakoff, 2000; Lakoff \& Johnson, 1980; Norman, 1988; Senge, 1990).

The course structures together framing conceptions, issues, and practices to create a decision frame or a thinking frame (a style) (Russo \& Schoemaker, 1990). They are ways of organizing thinking and discussion of issues of informing systems. The framing conceptions represent ways (grammars and vocabularies) of writing and talking about issues of some concern for future IS professionals. They are methods of constructing a "mental model" (Norman, 1988; Senge, 1990) by which a habit of thinking with the attending vocabulary is grown, or extended in the IS world (Hall, 1982). The thinking frame or mental model presents itself in the vocabularies and metaphors (Lakoff, 2002; Lakoff \& Johnson, 1980) in any discussion of an issue.

\section{An Assessing Rubric}

An assessing rubric depends upon vocabularies and metaphors as criteria by which a student's knowing of and ability in critical thinking in the subject matter is evaluated and judged. So, to assess critical thinking and knowing, the course must present the language to be used (reflective of the ideas in play), the metaphors and vocabularies. These metaphors are the global, the economic, the social, and the ethical; the framing conceptions. The vocabularies are the key terms of the framing conceptions, the metaphors signifying the key concepts which constitute the Whats in this logical space of discussing, the ontologies of critical thinking and knowing.

\section{Framing Conceptions}

The framing conceptions of the global, economic, social cultural, and ethical perspectives enframe and inform the issues of computing, and provide a ground for questions and analytical observations. The four frames, theories, are the grounds for making decisions and judgments about events and activities. The frames provide vocabularies and componential ideas; they are interpretative perspectives providing key terms usable as critical lenses focusing discussion.

Words and their application to issues are symbols (signs) of framing conceptions or systems of meanings. A word's use (or constellation of words) in a situation is part of the grammar, the logic of a framing conception. The framing conception provides the logic, the rationality of use; it also represents a set of associated practices. A framing conception is a system of meaning, a semantic structuring shared in a social and public space. The affairs of doing a discussion on a topic (an issue) reflect framing conceptions; they are the theories shared socially and publicly in the class which explain how affairs make sense; framing conceptions afford and constrain takes or interpretations (Lakoff, 2002); they provide boundaries of evaluation and appraisal.

The best kind of framing conception is one which becomes (over the course of a semester) an unconscious habit or style (practice) of doing and saying, seeing and hearing, of learning. They are personally, individually tacit; they are situationally, organizationally implicit. People in resultsoriented situations and organizations allow the framing conceptions to remain implicit, communicationally they sustain the "high context" (Hall, 1982); people in process-oriented situational in organizations cause the framing conceptions to be explic it in the structurings and procedures of 
situations and organizations, communicationally they sustain the "low context" (Hall, 1982; Hofstede \& Hofstede, 2005).

\section{Global Framing Conception}

Globalization is not something new. It has been around under many different names for a long time. To think critically about globalization, you must gather information about world-wide changes and events in political, cultural, technological, financial, national security, and ecological spheres (Friedman, 2000). But now the concept of globalization represents an evolutionary and integrative system pulling people and societies together into a common, world-wide market and flow of products, services, and knowledge (Friedman, 2000, 2006; Wheelan, 2002). "[Globalization]... is the inexorable integration of markets, nation-states and technologies..." (Friedman, 2000 , p. 8). It is a way of conceiving of the modernization of economies, of making markets efficient, and creating wealth and progress on political and social fronts by erasing geographical boundaries and cultural hindrances (Brake, 1997; Waters, 1995); this modernization creates a common soc ial cultural environment, progressive and democratic (Brake, 1997; Friedman, 2000, p. 9).

This international system integrating the world of business and the social cultural environment is a result of World Wide Web interconnectivity (Friedman, 2000, p. 10). This is what allows firms to be economically efficient and affords individuals access to and use of more different markets and know ledge. "Globalization is creating a world without walls, made possible by advances in communication and transportation technologies. This new perspective is seen in the rapid movement of ideas, capital, technology, and people across national borders" (Dunning, 1993, p. 40; Moran, Harris, \& Stripp, 1993, p. 299). This interconnectivity according to Friedman (2000, pp. 10, 12) and others (Brake, 1997; Levy, 2001) hampers the control (hegemony) of nation-states or societies over their internal affairs, especially their economic affairs.

International business competition constrains governmental policies and actions. This international system (globalization) is forcing deregulation and privatizing of many things (Friedman, 2000). Friedman (2000) uses the metaphor of the Golden Straitjacket, “...the defining politicoeconomic garment of this globalization era" (p. 102), to relate the modernization of countries' economies in order to compete in world-wide markets (Bhagwati, 2007, p. 3). "The driving idea behind globalization is free-market capitalism - the more you let market forces rule and the more you open your economy to free trade and competition, the more efficient and flourishing your economy will be" (Friedman, 2000, p. 8).

While all this seems good, globalization is a system which also brings conflict; a tension develops between individuals striving for prosperity and well-being and societies which are mired in ageold values and ethnic identities and conflicts (Brake, 1997; Dunning, 1993; Friedman, 2000, 2006). This is the conflict of modernity and tradition, as Friedman (2000, pp. 31-32) writes using the metaphors of the "Lexus" and the "Olive Tree" in discussing the narratives of the global and the local. The Lexus "... represents an equally fundamental, age-old human drive - the drive for sustenance, improvement, prosperity and modernization - as it is played out in today's globalization system" (Friedman, 2000, p.32). Olive trees "... represent everything that roots us, anchors us, identifies us and locates us in this world - whether it be belonging to a family, a community, a tribe, a nation, a religion or, most of all, a place called home" (Friedman, 2000, p.31). The clash of metaphors is the conflict of the modern and the traditional.

\section{Key ideas for making observations and asking questions}

Global, globalization, international system, integration, World Wide Web, technology, market, nation-state, democratization, freedom, tradition, modernity, modern, global-local narratives, cul- 
ture, metaphor, Lexus, Olive Tree, Golden Straitjacket, economy, polity, competition, hegemony, global dimens ions: politics, culture, technology, finance, national security, ecology; Global corporate values: caring, conf identiality, fairness, honesty, openness, partic ipation, respect, responsibility, results, sharing, unity, understanding.

\section{Economic Framing Conception}

That we do what we do to be happy, to ga in, what we think, are those things which bring us (or others) the greatest pleasure is perhaps the first most important economic assumption (Flynn, 2005). "Economics has an overly tautological view of happiness: The things we do must make us happy; otherwise we would not do them" (Wheelan, 2002, p. 154). Probably the second most important economic assumption is that people are rational about the ir choices and decisions in their lives. We make reasonable, "common-sense" decisions about how and why we want to be happy, to be pleasured. We unconsciously do what the economists call "cost-benefit analysis" (Flynn, 2005). Economics as a way of analysis makes conscious this "intuitive" logic in its terms of "cost-benefit analys is", and the "consequences" of behavior, the "motivations" of behavior, and the "incentives" of the situation and its circumstances (Flynn, 2005; Harford, 2008, Landsburg, 2007; Levitt \& Dubner, 2005; Wheelan, 2002).

Being rational is about making self-interested decisions in terms of their costs and benefits, or their "utility" for us, their use-value. "Economists suppose that you can compare all possible things that you may experience with a common measure of happiness or satisfaction that they call utility" (Flynn, 2005. p. 25). We do this in terms of our "self-interests" (O'Rourke, 2007, p. 9; Wheelan, 2002).

These decisions-of-value are made in given, everyday situations and their circumstances or, to use another economic term, in "markets", where judgments are to be made about the use-value of "commodities" or any other thing desired or think we need. A market is a situation where a thing's presence, as a resource, is dependent upon its availability in the market or situation. The market presents the availability, the scarcity of the desired object while the person is motivated by the perceived use-value, as an incentive, as well as the consideration of "trade-offs" of the "rational dec ision" (Flynn, 2005; Harford, 2008; Heilbroner, 1999; Landsburg, 2007).

\section{Key ideas for making observations and asking questions}

Utility, Incentive, Motivation, Cost - benefit, rational decision, Rationality: the right choice (decision), Market [situation: interaction]: Goods \& services, Supply \& demand, Price (worth, value, utility), Competition, Choice: decision, Pleasure, satisfaction, happiness, Perfect \& imperfect information, Perfect \& imperfect decision-making, Background know ledge, cultural norms, Perfect $\&$ imperfect altruism, Human nature: a social animal

\section{The Social Cultural Framing Conception}

The social cultural framing conception, as an analytic technique, can be defined or characterized in terms of a social group or network, relationships describable in terms of role and status, and its shared system of meanings, practices, and situations informing personal beliefs and behaviors (Geertz, 1973, p. 12; Hall, 1981; Hofstede \& Hofstede, 2005; Hooker, 2003; Spradley, 1980; Trompenaars, 1994, p. 14; Trompenaars \& Woolliams, 2003). A person stands in the midst of multiple and complex social cultural spaces. It is a social cultural landscape as an ecological system, or environment, in the head as much as in the world. The social cultural space is layered. A person participates in multiple social cultural environments (Hofstede \& Hofstede, 2005, pp. 1011; Karahanna et al., 2005). A fundamental social cultural space is the family; this space provides the basic beliefs, attitudes, behaviors informing an individual's personality. 
A person exists psychologically and socially within influential webs of historical and social relationships, social collectivities, and attending ecologies of meanings, what Gladwell calls "cultural legacies" (2008, p. 175); vocabularies and ideas, practices and situations are the daily bread of a person. Family, friends, organizations, professions, and society are some of the essential social networks, contextualizing behavior, affording and constraining actions, by means of attending ecologies of meanings. They are communities of action (Brown \& Duguid, 2000; Cohen \& Prusak, 2001).

Social cultural groups, as multiple and complex settings, have ways of dealing with power and influence, the uncertainty of affairs; in practices, they manifest individualistic or collective mind sets, as well as aggressive or nurturing approaches to people and situations; they also demonstrate short-sighted or far-sighted temporal outlooks (Gladwell, 2008; Hofstede \& Hofstede, 2005). Social cultural groups contextualize the flows of information, providing explic it or implic it ways and means for communicating (Hall, 1981). Social cultural groups are sources of values and norms by which individuals define (and redefine) relationships and situations (Goffman, 1974; Hofstede \& Hofstede, 2005); they provide the frames and mental models, implicit habitual views, which define reality (Fairhurst \& Sarr, 1996; Goffman, 1974; Lakoff \& Johnson, 1980; Norman, 1988; Russo \& Schoemaker, 1990).

The social cultural space is also a moral space. Our beliefs and behaviors are informed by a learned sense of what is good or evil, right or wrong which implicitly structures personal relationships and actions in situations (Chappell, 1993, p.71; Frankena, 1963; Georges, 2003; Goleman, 1995, 2006; Hauser, 2006). There are three basic approaches constituting this moral space fostering relational and social well-being (Lakoff, 2002, p. 380): "overall goodness" or the habit of doing good, "good versus bad consequences" or the pursuit of good results, and "categories of right or wrong action" or having rules intending to do the right thing (Hauser, 2006, p. 113).

\section{Key ideas for making observations and asking questions}

Social group(s): Interactive (networked) space: Community (communities) of common situations, practice \& action, multiple and complex webs of relationships and influence. Culture: Shared system(s) of meanings, practices, situations; Shared definitions of world \& situations. Norm: Explanatory principle or rule, standard or criterion of behavior. Situation + circumstances: Structure of behavior; Practices: habits of behavior; Mental models: implicit perspectives. Frames or Categories for organizing experience: Time \& Space, Power \& Uncertainty, Masculinity \& Femininity, Individualism \& Collectivism, Long Term \& Short Term Orientations High \& low contexts of communication: Common sense(s): codes \& polic ies: restricted \& elaborated. Metaphors, takes and language: Shared ontologies; Shared metaphysics. Moral grammar, moral codes, social intelligence, social savvy.

\section{The Ethical Framing Conception}

The ethical framing conception, as an analytic technique, represents a formal and systematic inquiry of the moral dimension of a social cultural space of which there are three basic approaches (see the social cultural framing conception above) (Chappell, 1993; MacIntyre, 1984; Szasz, 1974; Shirk, 1965; p. 23). "The word morality usually refers to the moral rules we follow, the values we have. Ethics is generally defined as theories about the rules; ethics questions and justifies the rules we live by..." (Rosenstand, 2006, p. 11). There are three fundamental and grand theories: deontologism, utilitarianism, and eudaimonism.

\section{Deontologism}

Deontologism is a theory which argues that any good intention to action must be universalizable and necessary as an obligation for all persons. The theory argues that every person is viewed as 
an "end" and not as a "means". This results in the "Golden Rule" as an ethical principle that we should do for others as we would have others do for us. (Frankena, 1963; Green, 1994; Mason, Mason \& Culan, 1995; Rosenstand, 2006, p. 240; Solomon, 1992a, 1992b).

\section{Utilitarianism}

Utilitarianism is a theory which argues that a good or beneficial result (or consequence) is the ground for considering the means of achieving the result a good state of affairs; a beneficial result is one which generates more "happiness" (or "pleasure") generally. The rule to be followed is one of "utility" or the use-value of the result (Chappell, 1993; Mill, 1957, p. 10; Rosenstand, 2006; Walton, 1988; Wiener, 1954). This gives us the "Golden Result" as an ethical principle that we should do the greatest resulting benefit for the most people. There are two versions: the best result of the best action and the best result of the best rule (or policy) (Frankena, 1963; Rosenstand, 2006; Williams, 1972, 2000).

\section{Eudaimonism}

Eudaimonis $m$ is a theory that argues that a virtuous life or a good character is the ground for life a life of excellence or virtue without excess. This theory is based on knowing one's strengths (virtue and values) and habitually acting on them moderately. One endeavors to act rightly and justifiably, for a good end or purpose, in all situations. This gives us the "Golden Mean" as an ethical principle that we should habitually and moderately act in the right manner, for the right reason, at the right time (Aristotle, 2004; Frankena, 1963; MacIntyre, 1984; Rosenstand, 2006; Shirk, 1965; Solomon, 1992a, 1992b, 1997; Williams, 1972)

\section{Key ideas for making observations and asking questions}

Deontologism: A universalizable and necessary rule justifies an action as right or good. The Golden Rule: do for others as you would have them do for you. Utilitarianism: maxim of utility, the Golden Result: that a moral act is one that results in the most pleasure or happiness with the least pain. Egoist version: the greatest good for oneself Universalist version: The greatest good for the greatest number. Act-utilitarianism: actions are judged by the ir good results. Ruleutilitarianism: rules or policies for actions are judged by greatest possible benefits intended. Eudaimonism: Highest moral good is self actualization and growth in fulfilling potential. Personal well-being or eudaimonia is the ultimate criterion by which character, action, and consequences are judged. Virtue (Excellence) is know ledge Happiness is self actualization and righteousness The Golden Mean: Virtuous action is a habit of right action in moderation leading to eudaimonia (well-being).

\section{Practices of the Course}

The focus also is on the course's practices. What are the practices which grow this habit? The course's practices are represented in the documents produced by the practices. The documents produced are ways of making things, affairs present in situations and ways of grounding and structuring discussions of issues as learning situations; they objectify and express explicitly observations and questions in the classroom (Zimmerman, 1974).

There are four different kinds of documents. The first type of documents (called Assignment Reports: AR1 and AR2) are initial forays into the subject matter of the framing conceptions of the course. These are annotated bibliographies. The framing conceptions are the global (business world), the economic, the social cultural, and the ethical. Annotated bibliographic reports (AR1 and AR2) are used to introduce the student to the framing conceptions in terms of their basic definitions and key ideas and terms. These begin the practice of building an accumulation of insightful resources about issues. These initial sources are added to throughout the semester via the 


\section{Modeling an Asse ssing Rubric}

other types of ARs. An annotation includes a short abstract or summary of the ideas pertaining to the framing conception, e.g., the global, the economic, the social cultural, or the ethical, key terms (to help remember and to build a vocabulary of discourse, and to do future research), and if possible, a pertinent quotation (the best kind are usually definitions of key terms or focused ides).

A second set of documents (Assignment Reports AR3-AR8) report upon the application of questions raised in the framing conceptions to selected issues of computing (information use and information system design and deve lopment). They are discussions of personal observations grounded in the frames about an issue. Discussion here means a descriptive and analytical narrative which combines personal observations with observations gathered from articles which are chosen because they say something about the issue in question and present some aspects (key words) of the framing conceptions. Every report on an issue has 6 parts: the descriptive summary of the case (based on Spinello, 2003), a section for observations based on the framing conceptions, and a question which each student brings to the classroom discussion and which (in the planned discussion of the course) leads to further observation made about the issue.

A third set of documents are the checks for "quality control" or the examinations (there are three) which ask the student to describe and elaborate the framing conceptions and the ir implicative questions leading to observations: the actual basis for critical thinking (in exam1), or to apply the framing conceptions to an issue (exam2 and exam3).

A fourth set of documents (saved as PowerPoint slides for every session) result from the practice of small group discussion which, in turn, acts as a basis for large group discussion (the whole class) of an issue. The practice of small group discussion relies upon the practice of doing the reports (AR3-AR8).

\section{The Rubric}

A rubric (since medieval times, printed in red ink) is a rule or a set variations of a rule or direction for doing an action as a ritualistic part of a situation. Evaluating students' work and efforts is a ritual every teacher "knows". A rubric is a rule which structures the questions: How do you know that some one knows what they are talking about, or writing about? How do you evaluate the level of competence in the subject matter and in thinking about the issue at hand? A rubric is used to evaluate and grade a student's performance in some assignment. The course's rubric evaluates performance and determines a level of competency or knowledge and its application in the use of key words or terms, hence key ideas, in writing a report about a specific computing issue. The key words and ideas are grounded in the four framing conceptions and, over a semester, are developed and elaborated by the addition of new sources (outside reading) researched as background to each issue.

An important part of the rubric for the course is the use of key terms as defined in the framing conceptions. Key terms are signs of key ideas and of the framing conceptions (see Lakoff \& Johnson, 1980) applied in a discussion of issues. Basically, a rubric posits that words, when, where, and how used in writing (or discussion), show levels of competence in thinking and writing stuff down, that is, describing and analyzing a computing (information system) issue.

The rubric requires an explic it document (the Assignment Reports: AR1 - AR8, and exams) which demonstrates a student's understanding of the subject matter applied to issues by an appropriate and persuasive use of language (key terms and ideas). The explicit use of vocabulary and logic yields a documentable conceptual map observable in the use of key terms and ideas of the framing conceptions in a report's discussion of an issue or topic. Evaluating a student's efforts in terms of a conceptual map is making a observation about low density (use) of key terms to a density of key terms. This is the conceptual map aspect of the rubric. The rubric also defines as a dimension of a report its syntactical use of language concerning sentence structure and spellings. 
The rubric further defines the informational quality as ranging from be ing a dense (informative, and possibly interesting) read to a sparse (noninformative, and boring) read. A final level of the rubric concerns the appropriate and persuasive use of the researched sources on the topic. As a result, the rubric affords a judgment about a student's know ledge and understanding about a topic or issue, and an application of the four framing conceptions to thinking critically (describing and analyzing) to an issue. Thus, a student's style of decision making about a topic or issue is enhanced.

\section{Conclusion}

The paper presents a rubric for evaluating students' abilities and understandings in critically applying the course's subject matter (the global, economic, social cultural, and ethical frames) and researched external sources to computing or information system issues. The rubric is a structure to assess the course's goal of students developing a habit, implicitly cons isting of the four frames to thinking critically about current and future issues which they as information system professionals do or may encounter.

The paper also provides a discussion of the global, economic, social cultural, and ethical framing conceptions or frames as the grounds for constructing a rubric aimed at evaluating students' efforts.

\section{References}

Bhagwati, J. (2007). In defense of globalization. Oxford: Oxford University Press.

Brake, T. (1997). The global leader: Critical factors for creating the world class organization. Chicago: Irwin Professional Publishing.

Brown, J. S., \& Duguid, P. (2000). The social life of information. Boston: Harvard Business School Press.

Chappell, T. (1993). The soul of a business: Managing for profit and the common good. New York: Bantam Books.

Choate, P. (2008). Dangerous business: The risks of globalization. New York: Alfred A. Knopf.

Córdobra, J. (2007a). Developing inclusion and critical reflection in information system design. Organization, 14(6), 909-927.

Córdobra, J. (2007b). A critical systems view of power-ethics interactions in information systems evaluation. Information Resources Management Journal, 20(2), 74-89.

Dunning, J. H. (1993). The globalization of business: The challenge of the 1990s. London and New York: Routledge.

Fairhurst, G. T., \& Sarr, R. A. (1996). The art of framing: Managing the language ofleadership. San Francisco: Jossey-Bass.

Flynn, S. M. (2005). Economics for dummies. Indianapolis, IN: W iley Publishing.

Frankena, W. K. (1963). Ethics. Engle wood Cliffs, NJ: Prentice-Hall.

Fried man, T. L. (2000). The Lexus and the olive tree. New York: Farrar, Straus and Girou x.

Fried man, T. L. (2006). The world is flat. New York: Farrar, Straus and Giroux.

Gannon, M. J. (2001). Understanding global cultures: Metaphorical journeys through 23 nations (2nd ed.). Thous and Oakes, CA: Sage.

Geertz, C. (1973). The interpretation of cultures. New York: Basic Books.

Georges, T. M. (2003). Digital soul: Intelligent machines and human values. Boulder, CO: Westview Press. 


\section{Modeling an Asse ssing Rubric}

Go ffman, E. (1974). Frame analysis: An essay on the organization of experience. Cambridge: Harvard University Press.

Goleman, D. (1995). Emotional intelligence. New York: Bantam Books Random House.

Goleman, D. (2006). Social intelligence. New York: Bantam Books Random House.

Green, R. M. (1994). The ethical manager: A new method for business ethics. New York: Mac millan College Publishing.

Hall, E. T. (1981). Beyond culture. New York: Anchor Books Random House.

Halpern, D. F. (1998). Teaching critical thinking for transfer across domains. American Psychologist, 53(4), 1-7.

Harford, T. (2006). The undercover economist. Oxford: Oxford Un iversity Press.

Harford, T. (2008). The logic of life: The rational economics of an irrational world. New York: Random House.

Hauser, G. A. (1986). Introduction to rhetorical theory. Prospect Heights, IL: Waveland Press.

Hauser, M. D. (2006). Moral minds: The nature of right and wrong. New York: HarperCollins.

Heilbroner, R. L. (1999). The worldly philosophers (7th ed.). New York: Simon \& Schuster.

Hofstede, G., \& Hofstede, G. J. (2005). Culture and organizations: Software of the mind (2nd ed.). New York: McGraw-Hill.

Hooker, J. (2003). Working across cultures. Stanford, CA: Stanford University Press.

Karahanna, E., Evaristo, J. R., \& Strite, M. (2005). Levels of culture and individual behavior: An integrative perspective. Journal of Global Information Management, 13(2), 1 - 19.

Lakoff, R. T. (2000). The language war. Berkeley: University of California Press.

Lakoff, G., \& Johnson, M. (1980). Metaphors we live by. Chicago and London: The Un iversity of Chicago Press.

Lakoff, G. (2002). Moral politics: How liberals and conservatives think (2nd ed.). Chicago and London: University of Chicago Press.

Landsburg, S. E. (2007). More sex is safer sex: The unconventional wisdom of economics. New York: Free Press.

Levitt, S. D., \& Dubner, S. J. (2005). Freakonomics. New York: HarperCollins.

Levy, P. (2001). Cyberculture. (Trans. R. Bonomo). Minneapolis: University of Minnesota Press.

Lewis, R. D. (2006). When cultures collide: Leading across cultures. Boston: Nicholas Brealey International.

MacIntyre, A. (1984). After virtue: A study in moral theory (2nd ed.). Notre Dame, IN: University of Notre Dame Press.

Mason, R. O., Mason, F. M., \& Culan, M. J. (1995). Ethics of information management. Thous and Oakes, CA: Sage.

McGann, S. T., Frost, R. D., Matta, V., \& Huang, W. (2007). Meeting the challenge of IS curriculu m modernization: A guide to overhaul, integration, and continuous improvement. Journal of Information Systems Education, 18(1), 49-61.

Moran, R. T., Harris, P. R., \& Stripp, W. G. (1993). Developing the global organization. Houston: Gu lf Publishing.

Norman, D. A. (1988). The design of everyday things. New York: Currency Doubleday.

O'Rourke, P. J. (2007). On the wealth of nations. New York: Atlantic Monthly Press. 
Paul, R., \& Elder, L. (2006). Critical thinking concepts and tools. Dillon Beach, CA: Foundation for Critical Thin king.

Rowe, A. J., \& Mason, R. O. (1989). Managing with style: A guide to understanding, assessing, and improving decision making. San Francisco, CA : Jossey-Bass.

Russo, J. E., \& Schoemaker, P. J. H. (1990). Decision traps: Ten barriers to brilliant decision-making and how to overcome them. New York: Simon \& Schuster.

Senge, P. M. (1990). The fifth discipline: The art and practice of the learning organization. New York: Currency Doubleday.

Shirk, E. (1965). The ethical dimension: An approach to the philosophy of values and valuing. New York: Meredith.

Solo mon, R. C. (1992a). Ethics and excellence: Cooperation and integrity in business. New York \& Oxford: Oxford University Press.

Solomon, R. C. (1992b). Morality and the good life (2nd ed.). New York: Mc Graw-Hill.

Solo mon, R. C. (1997). It's good business: Ethics and free enterprise for the new millennium. Lanham, MD: Rowman and Littlefield.

Spinello, Richard A. (2003). Case studies in information technology ethics (2nd ed.). Upper Saddle River, $\mathrm{NJ}$ : Prentice Hall Pearson Education.

Spradley, J. P. (1980). Participant observation. New York: Wadsworth Thomson Learning.

Szasz, T. S. (1974). The myth of mental illness: Foundations of a theory of personal conduct. New York: Harper \& Row.

Tro mpenaars, F. (1994). Riding the waves of culture: Understanding diversity in global business. London: The Econo mist Books.

Trompenaars, F. \& Woolliams, P. (2003). Business across cultures. Chichester, England: Capstone.

Walton, C. C. (1988). The moral manager. New York: Ballinger Harper \& Row.

Waters, M. (1995). Globalization. London and New York: Routledge.

Wheelan, C. (2002). Naked economics: Undressing the dismal science. New York: W. W. Norton.

Whorf, B. L. (1956). Science and linguistics. In J. B. Carroll (Ed.), Language, thought, and reality: Selected writings of Benjamin Lee Whorf. Cambridge, MA: MIT Press.

Wiener, N. (1954). The human use of human beings: Cybernetics and society. London: Free Association Books.

Williams, B. (1972). Morality: An introduction to ethics. New York: Harper Torchbooks Harper \& Row.

Williams, O. F. (Ed). (2000). Global codes of conduct: An idea whose time has come. Notre Dame, IN: University of Notre Dame Press. 


\section{Biography}

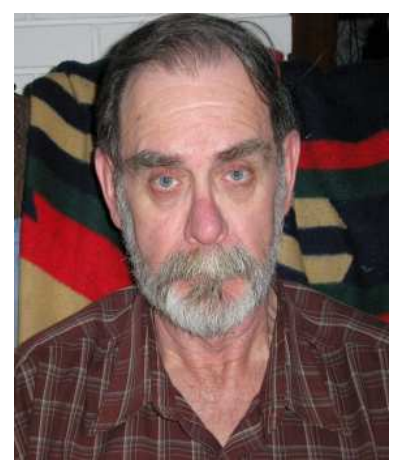

Robert Jose ph Skovira is University Professor of Computer and Information Systems in the Department of Computer and Information Systems at Robert Morris University, Moon Twp (Pittsburgh) PA USA. He has taught undergraduate and graduate (MS) courses including Java Programming, Secure Programming, Global, Economic, Social, and Ethical Issues of Computing, Decision Support Systems, Information Design, and Ethical and Legal Issues of Technology. In the Doctor of Science program, he has taught Ethnography of Information Systems, Readings in Information Systems and Communications Research, and Writing the Proposal for Research courses. He has been a visiting professor at Comenius University, Bratis lava, Slovakia, in 1997 and 2006. Research interests include the anthropology of information, information and information system use within organizations (the infoscape, politics of information, information system bias), cultural and moral frameworks of information and information use, decision making and know ledge management, informing objects, information design and thinking visually. 